\title{
Paweł Gondek, Projekt autonomicznej filozofii realistycznej. Mieczysława A. Krapca i Stanisława Kamińskiego teoria bytu, Polskie Towarzystwo Tomasza z Akwinu i Wydawnictwo KUL, Lublin 2015, ss. 316, indeks osobowy i rzeczowy, bibliografia.
}

Książka Pawła Gondka jest krytycznym opracowaniem - pierwszym tak obszernym i szczegółowym - koncepcji filozofii wypracowanej przez kluczowych przedstawicieli lubelskiej szkoły filozoficznej: Mieczysława A. Krąpca i Stanisława Kamińskiego (wyrażenie „lubelska szkoła filozoficzna” pisane jest małą literą, więc Autor najwyraźniej nie traktuje go jako nazwy własnej). Rację ma Gondek, iż nie istnieją „do tej pory opracowania całościowo analizujące problematykę teorii bytu Krąpca i Kamińskiego. Istnieją natomiast autorzy oraz prace kontynuujące takie rozumienie filozofii” (s. 18). Są też oczywiście prace krytykujące tę koncepcję teorii bytu, w literaturze filozoficznej (także zagranicznej) funkcjonuje termin „lubelska szkoła filozoficzna”, są prace (głównie artykuły) dotyczące poszczególnych filozofów tej tradycji, natomiast nie powstały monografie. $Z$ tej właśnie racji książka jest oryginalnym i ważnym wkładem w filozofię.

Autor starannie tłumaczy się z tytułu pracy. Wybór postaci uzasadniony jest tym, że choć były inne koncepcje, M. Krąpiec i S. Kamiński wypracowali najbardziej wszechstronny i dojrzały projekt uprawiania filozofii. Termin „projekt” zaczerpnął z artykułu Józefa Herbuta (również filozofa z KUL). Termin ten może oznaczać program filozoficznego wyjaśniania albo też zbiór tez wyznaczających model wiedzy filozoficznej. Choć Gondek explicite tego nie formułuje, oba znaczenia funkcjonują w monografii. Równie starannie tłumaczy się z wykorzystania terminu „teoria bytu”. Terminu tego - zamiennie z terminem „filozofia bytu” i „metafizyka realistyczna” - używają zarówno Krąpiec jak i Kamiński, a zdaniem Gondka określenie to powstało dla odróżnienia filozoficznego projektu obu myślicieli od tradycyjnie pojętego tomizmu, 
choć oczywiście projekt ten wyrasta z tradycji tomistycznej w jej wersji egzystencjalnej. Gondek uważa, iż na tle współczesnych tradycji filozofowania jest to projekt nowatorski. Ów projekt - twierdzi - należy widzieć jako „próbę przezwyciężenia $z$ jednej strony tendencji metaprzedmiotowego uprawiania filozofii, z drugiej tendencji do uprawiania filozofii jako nabudowanej na wynikach nauk szczegółowych” (s. 8), a ponadto „jako powrót do tzw. poznania mądrościowego, w którym sama metafizyka staje się metodą wyjaśniania całej rzeczywistości” (s. 8). W kontekście krytyki teorii bytu Gondek stawia wiodące pytanie pracy: czy możliwe jest zbudowanie autonomicznej teorii bytu? Odpowiada na nie twierdząco, pokazując przykład filozoficznej koncepcji rozwijanej przez Mieczysława Alberta Krąpca i Stanisława Kamińskiego.

Książka, prócz wstępu i zakończenia, zawiera cztery rozdziały: I pt. Filozofia jako teoria bytu, II pt. Metodologiczne podstawy autonomiczności teorii bytu, III pt. Systemowe uzasadnienie autonomiczności teorii bytu oraz IV pt. Jedność autonomicznej teorii bytu. Zaopatrzona jest również w streszczenie w języku angielskim, indeks osobowy, indeks przedmiotowy, obszerną bibliografię, spis treści w języku angielskim i spis treści w języku polskim.

Rezultatem analiz Gondka jest następująca teza: ,autonomiczność w uwyraźnianiu przedmiotu metafizyki oraz towarzyszących mu metod wyznacza porządek badań metametafizycznych, których zwieńczeniem jest sformułowanie szczegółowych dyscyplin filozoficznych, stanowiących właściwy wyznacznik jedności teorii bytu” (s. 12). Innymi słowy, w koncepcji Krąpca i Kamińskiego autonomiczność metafizyki jest gwarantowana odrębnym przedmiotem i metodami badań, a konieczną pochodną ujęcia przedmiotowego jest takie metaprzedmiotowe wyodrębnienie dyscyplin, które gwarantuje metafizyce spójność i jedność. Autor zaznacza, że jego „monografia nie ma charakteru tylko historyczno-filozoficznego namysłu nad przywołaną koncepcją teorii bytu. Podejmuje się w niej raczej próbę skoncentrowania się nad formami współczesnego uprawiania metametafizyki, w kontekście projektu metafizyki realistycznej" (s. 13). To ostatnie sformułowanie jest jednak zdecydowanie „na wyrost”, ponieważ monografia ma faktycznie charakter analiz immanentnych. Szersze analizy dotyczą jedynie polemik, jakie toczyli obaj myśliciele już w obrębie szkoły lubelskiej, np. polemiki z Antonim Stępniem na temat 
statusu teorii poznania, z ks. Tadeuszem Styczniem na temat przedmiotu etyki (także z Mieczysławem Gogaczem o przedmiot metafizyki). Skrótowe przypomnienie owych polemik - zasługujących zresztą na osobną monografię - jest natomiast istotną zaletę książki Gondka. Pokazuje ono zarówno styl uprawiania filozofii w szkole lubelskiej, jak i jej dynamizm, a ponadto pozwala postawić i rozwiązywać nowe - i aktualne - problemy w tej tradycji. I choć nie ma znaczących nawiązań do „współczesnych form uprawiania metametafizyki”, Autor słusznie uważa koncepcję Krąpca i Kamińskiego za projekt filozofowania przedmiotowego, a nie metaprzedmiotowego oraz autonomicznego wobec nauk szczegółowych i teologii.

Czytelnik może natomiast mieć trudności z interpretacją często używanego przedrostka „meta”, gdyż czasem Autor krytykuje metaprzedmiotową filozofię, a czasem deklaruje uprawianie metametafizyki. Przydałyby się tu odróżnienia metodologiczne, które chętnie w swych wykładach i pracach stosował S. Kamiński: krytyka metaprzedmiotowego uprawiania filozofii dotyczy traktowania filozofii jako swego rodzaju metanauki, np. jako opracowania wyników nauk szczegółowych, czy jako analizy języka nauki; konieczne jest natomiast uprawianie metafilozofii (jak choćby metametafizyki) - np. metodologii metafizyki, historii metafizyki (i metafizyków). W książce Gondka ujawnia się natomiast pewna specyfika filozofowania, choć nie jest explicite analizowana: w filozofii proste odróżnienie poziomu i metapoziomu analiz jest trudne - o ile w ogóle możliwe. Historia fizyki nie należy do fizyki, co nie jest tak oczywiste w przypadku historii filozofii, choćby dlatego, że rozumienie filozofii wyznacza, jakie dzieła i idee zaliczymy do filozoficznych. $Z$ tego względu pokazanie, iż uwyraźnianie przedmiotu metafizyki wyznacza rozstrzygnięcia metaprzedmiotowe uważam za istotny wynik analiz Pawła Gondka. I choć osadzenie analiz koncepcji Krąpca i Kamińskiego we współczesnych dyskusjach jest niewielkie, monografia pokazuje, iż jest to koncepcja wartościowa i spójna. Skontrastowanie jej ze współczesnymi koncepcjami powinno stanowić kolejny projekt badawczy, nawet jeśli - choć nie jestem skłonna uznać tego twierdzenia bez zastrzeżeń - „autonomicznie rozumiana filozofia jest uprawiana peryferyjnie, $z$ tego względu nie posiada wielkiego wpływu na współczesne oblicze prowadzonych rozważań filozoficznych” (s. 7). Jasne jest natomiast, 
że sam Paweł Gondek jest zwolennikiem autonomicznego uprawiania teorii bytu i proponuje ten sposób uprawiania autonomicznej metafizyki realistycznej jako twórczy i poprawny sposób uprawiania filozofii po prostu. Tym samym wychodzi poza historyczno-metodologiczne immanentne analizy cudzych poglądów i zajmuje własne, wyraźne stanowisko. W kontekście żywionej przez niego samego oceny tego sposobu filozofowania jako marginalnego, niepopularnego i ośmieszanego, jest to zaiste akt filozoficznej odwagi.

Rozdział pierwszy książki stanowi wprowadzenie do właściwych analiz. Autor omawia krótko lubelską szkołę filozoficzną, a następnie dyskusje metametafizyczne toczące się w tej szkole. Wskazuje na inspiracje zaczerpnięte z tomizmu egzystencjalnego oraz cztery podejścia do eksplikacji rozumienia bytu, sposobów uzasadniania oraz budowania systemu metafizyki: S. Swieżawskiego, M.A. Krąpca i S. Kamińskiego, A.B. Stępnia oraz M. Gogacza. Gondek broni tu poglądu, iż szkołę lubelska należy charakteryzować poprzez tezy przedmiotowe, a nie poprzez kryteria historyczne. Jako wspólne dla wymienionych podejść - a zarazem konstytutywne dla lubelskiej szkoły filozoficznej-wymienia dwie tezy: (1) przedmiotem metafizyki jest byt jako istniejący (stąd akcentowanie aktu istnienia przy stawianiu i rozwiązywaniu problemów) oraz (2) esencjalizm ukazuje niepełną wizję świata. Omawiając zaś filozoficzne determinanty współpracy naukowej M.A. Krąpca i S. Kamińskiego, twierdzi, iż właśnie ta współpraca pozwoliła wypracować nowatorski i oryginalny projekt metafizyki realistycznej, który nie sprowadzał się do recepcji tomizmu egzystencjalnego. W tym rozdziale pojawia się już teza o autonomii filozofii (s. 57). Nie ma natomiast analiz, jak rozumiana jest autonomia i jakie są jej odmiany (np. poznawcza, metodologiczna, instytucjonalna), choć S. Kamiński pisał o tym wielokrotnie. Czytelnik nie zaznajomiony solidnie z tradycja szkoły lubelskiej musi wobec tego polegać na własnym, zapewne intuicyjnym, rozumieniu terminu ,autonomia”.

Rozdział II ma na celu ukazanie metodologicznych podstaw teorii bytu. Autor pisze: „Teoria bytu wysuwa jako podstawowy postulat racjonalne wyjaśnienie rzeczywistości w aspekcie ogólnoegzystencjalnym, w ramach którego nie korzysta $z$ wyników innych nauk oraz dąży do ostatecznego wyjaśnienia rzeczywistości” (s. 87). Powyższe sformułowanie jest nieco niezgrabne, gdyż 
w odniesieniu do wyjaśniania rzeczywistości raz jest mowa o postulacie, a raz o „dążeniu do”. Sądzę, że należałoby po prostu podać cel przedmiotowy teorii bytu: celem jest racjonalne i ostatecznościowe wyjaśnienie rzeczywistości w aspekcie ogólnoegzystencjalnym; a następnie objaśnić określenia występujące w tym sformułowaniu. Objaśnienia takie są oczywiście obecne w monografii, ale czytelnik musi je rekonstruować z toku wywodów. Zwłaszcza sformułowanie „ogólnoegzystencjalny” nie jest oczywiste, skoro nie pojawia się explicite aspekt „szczegółowoegzystencjalny”. Rozdział rozpoczyna się od analiz problemu autonomii filozofii, ale w dalszym ciągu nie znajdujemy analiz, co to znaczy, że jakaś dyscyplina (nauka) jest autonomiczna i na czym polega problem autonomiczności jakiejkolwiek dyscypliny. Autor od razu przechodzi do scharakteryzowania różnych koncepcji filozofii jako sztuki życia, poszukiwania pierwszej zasady rzeczywistości, jako „służki teologii” czy logiki wiedzy. Po drodze dowiadujemy się jeszcze o podziałach nauk u rozmaitych myślicieli. Słusznie Autor podkreśla, że autonomiczność filozofii jest kwestią stosunku filozofii z jednej strony do nauk szczegółowych, a $z$ drugiej - do teologii. Nie podejmuje natomiast kwestii relacji nauki do mądrości, choć wcześniej wskazywał, iż „metafizykę trzeba traktować nie tylko jako drogę do mądrości, ale także jako wiedzę wywołaną przez mądrość" (s. 58). Słusznie też Autor twierdzi, że współcześnie obserwujemy tendencje unifikacjonistyczne i antydemarkacjonistyczne. Głosi jednak tezę, która może spowodować nieporozumienia co do stanowiska Krąpca i Kamińskiego w sprawie relacji nauki do filozofii. Paweł Gondek pisze: „Filozofia, wchodząc w strukturalne związki z naukami szczegółowymi, niejednokrotnie uczestniczy w procesach integrujących badania naukowe, pełniąc w nich głównie rolę 'koordynatora' epistemologiczno-metodologicznego. Natomiast traci wartość metafizyczne wyjaśnianie rzeczywistości” (s. 96). Wydaje się, że zostały tu bezpodstawnie utożsamione dwie rzeczy: traktowanie filozofii jako dyscypliny metaprzedmiotowej (jej przedmiotem są wyniki nauki) i rolę filozofii w nauce. Z pewnością S. Kamiński uważał, iż filozofia - właśnie jako dyscyplina autonomiczna - odgrywa w nauce ważną i niezbywalną rolę, a nawet twierdził, że rozstrzygnięcia filozoficzne determinują, co się uważa za naukę. Źródłem problemu jest, jak sądzę, pominięcie solidnych analiz możliwych związków 
między dyscyplinami, gdyż wtedy stałoby się jasne, kiedy zależności strukturalne nie zagrażają autonomiczności filozofii, a kiedy jej zagrażają. Ponadto powyższa krytyka filozofii „wchodzącej w strukturalne związki z naukami szczegółowymi” jest na pierwszy rzut oka niespójna z podkreślaniem, iż zdaniem Krąpca (a i Kamińskiego!) filozofia może ukazać najbardziej ogólne podstawy istnienia i funkcjonowania poszczególnych nauk, oraz ,jest władna także dokonać oceny wyników nauk szczegółowych oraz ich syntezy” (s. 55).

Brak systematycznych analiz autonomiczności i związków między naukami spowodował w rozważaniach Gondka pomieszanie terminów „filozofia nauki”, „filozofia naukowa” i „filozofia jako metanauka”. Filozofia nauki ma za swój przedmiot naukę i można ją uprawiać klasycznie (metafizyka nauki), albo nieklasycznie. Wszak sam Kamiński uprawiał filozofię nauki. „Filozofia naukowa” wykorzystuje w punkcie wyjścia dane czerpane z nauk szczegółowych, ale to służy jej do rozwiązywania klasycznych problemów filozoficznych; zaś „filozofia jako metanauka” oznacza koncepcję filozofii, która nie ma swego własnego przedmiotu w rzeczywistości, ale zajmuje się np. analizą języka (choć niekoniecznie języka nauki). Te ujęcia należy z kolei odróżnić od „filozofii w nauce", gdzie podejmowane są analizy pojęć pojawiających się i w filozofii, i w nauce, np. czas, przestrzeń, przyczynowość. I choć Autor przywołuje postaci J. Życińskiego i M. Hellera, którzy „filozofię w nauce” uprawiali, owych odróżnień nie czyni. Natomiast doskonale - choć może nie najprościej pokazana jest różnica, pozwalająca na wyodrębnienie nauk szczegółowych (realnych i formalnych) i filozofii: „dokonanie tego rozróżnienia jest uwarunkowane już nie tylko samym przedmiotem, ale także sposobem racjonalnego ‘wydobywania' z przedmiotu różnych porządków jego ujmowania” (s. 101), a wyróżnianie nauk „nie ma na celu izolowanie poszczególnych typów wiedzy, tylko uporządkowanie sposobów ich uprawiania, w oparciu o odpowiednio ujęty przedmiot badań. Wyodrębnienie przedmiotu determinuje następne czynności poznawcze w postaci określonych metod badawczych (...). Ogólno-egzystencjalny aspekt badań wyznacza charakter filozofii jako nauki ogólnej, która wyjaśnia całą rzeczywistość w aspekcie jej istnienia. Nie ma ona na celu szczegółowych rozróżnień w zakresie treściowego ujmowania poznawanych rzeczy, ale poszukuje zasad i przyczyn dla tego co jest” (s. 103). Szczegółowe 
analizy sprawiają, że odpowiedzi na zarzuty pod adresem klasycznej teorii bytu stają się wiarygodne. Na szczególne podkreślenie zasługuje następujący argument: filozofia nie może wychodzić od wyników nauk szczegółowych, ponieważ determinacja przedmiotu filozofii odbywałaby się przez dane już uteoretycznione, pochodzące z innego porządku badawczego. Argument ten choć Gondek tego nie przywołuje - jest wzmocniony wynikami filozofii nauki (nie: filozofii naukowej) o uteoretycznieniu danych empirycznych już w obrębie badań naukowych. Rozwinięcie tego argumentu w oparciu, z jednej strony o analizy Krąpca i Kamińskiego, a z drugiej - o współczesną analizę nauki uważam za poważny pomysł badawczy, co pośrednio wskazuje też na płodność - jedno z kryteriów naukowości - analiz przedstawionych w monografii.

Kluczowe rozważania rozdziału II dotyczą metodologicznych uwarunkowań wyodrębniania przedmiotu metafizyki oraz uzasadniania tez. Gondek twierdzi, że Krąpiec i Kamiński, dystansując się w punkcie wyjścia tak od wyników nauk, jak i od wszelkich apriorycznych podejść do przedmiotu, muszą rozwiązać następujący problem: jak ująć przedmiot, by z jednej strony był rzeczywisty, a z drugiej - umożliwiał uzasadnianie tez metafizyki. Stąd obaj myśliciele stoją przed wyzwaniem bezzałożeniowego ujęcia przedmiotu oraz wskazania nieapriorycznych warunków determinacji przedmiotu metafizyki. Gondek pokazuje, jak te trudności zostają rozwiązane poprzez idee „konstrukcji naturalnej” i „konstrukcji sztucznej”, w której „spontaniczna wiedza o świecie zostaje spartykularyzowana i zorganizowana" (s. 114; to daje nauki szczególowe), a wyodrębnienie filozofii następuje w postaci „zreflektowania tej pierwotnej postaci poznawczej, w której nastąpiło spontaniczne ujęcie tego, co jest” (s. 114). Natomiast „aby pozostać w zgodzie z rzeczywistością, koniecznym elementem budowania filozofii jest precyzyjny namysł nad czynnikami, jakie spełnia przedmiot właściwy filozofii” (s. 115). To niezbyt jasne zdanie o „spełnianiu czynników przez przedmiot właściwy filozofii” głosi, iż badania przedmiotowe i namysł metaprzedmiotowy są ze sobą nierozerwalnie splecione. Gondek omawia postawione przez Krąpca i Kamińskiego warunki dla określenia przedmiotu właściwego filozofii: realizm (oparcie tez na rzeczywistości), uniwersalizm (przedmiotem ma być wszystko, a więc nie tylko rzeczy (substancje), ale i porządek przypadłościowy i relacyjny) oraz neutralizm 
(ujęcie tego, co jest, choć przy neutralizacji treści; jest „coś”, a nie byt określonej kategorii), który okazuje się warunkiem kluczowym dla postulowanej przez Krąpca i Kamińskiego teorii bytu. Kolejne rozważania dotyczą specyfiki uzasadniania tez teorii bytu. Pierwszą specyfikę stanowi wykorzystanie metody historyzmu metodologicznego (czy, jak później Autor to nazwie, metody indukcji doksograficznej, s. 122), polegającej na formułowaniu tez w kontekście historycznych stanowisk, odnoszących się do danego zagadnienia. Dyskusja z wcześniejszymi stanowiskami jest „prowadzona w celu wydobycia pełniejszego sensu badanego zagadnienia” i ma "służyć dochodzeniu do prawdy" (s. 123). Autor słusznie zauważa ahistoryzm współcześnie uprawianej filozofii (nie mówi tego wprost - ale chodzi o filozofię analityczną). Znaczenie tej metody - podkreśla - „ujawnia się właściwie w dwóch porządkach: jako podstawa formułowania problemów (funkcja heurystyczna) i jako czynnik, na podstawie którego przyjmowane są tezy (funkcja uzasadniająca)" (s. 128). O ile indukcja jako metoda heurystyczna jest dobrze w monografii opracowana, to jako metoda uzasadniania tez pozostaje właściwie w sferze deklaracji i powtórzeń. Także twierdzenia dotyczące metod dowodzenia tez teorii bytu domagają się dodatkowych objaśnień. Szczególnie ważne jest tu twierdzenie, że „specyfika dowodzenia tez $\mathrm{w}$ teorii bytu opiera się na wnioskowaniu redukcyjnym, które wspomagane jest przez argumentację apagogiczną i elenktyczną oraz występuje w odniesieniu do skonstruowanego na bazie stanów rzeczowych przedmiotu filozofii" (s. 131). W tym punkcie Gondek dotyka jednej z najistotniejszych rzeczy w metodologii metafizyki: możliwości formalizacji oraz potraktowania wniosku wnioskowania redukcyjnego jako koniecznego, mimo że jest to wnioskowanie jedynie uprawdopodobniające. Autor przywołuje tezę S. Kamińskiego, że procedura dochodzenia do tez metafizyki ma charakter intuicyjno-redukcyjny. Podejście to opiera się na akcie intuicji intelektualnej jako bezdyskursywnym i bezpośrednim akcie poznawczym, polegającym „na ujmowaniu relacji występujących w rzeczach i między rzeczami w aspekcie ogólno-egzystencjalnym” (s. 131). Co daje taki akt? Wydaje się, że daje coś, co można uznać za fakt dany do wyjaśnienia, a intuicja intelektualna jako rodzaj bezpośredniego doświadczenia rzeczywistości stanowi uzasadnienie akceptacji. Wyjaśnienie ma zaś charakter redukcyjny, tj. ów fakt ujęty aktem 
intuicji intelektualnej jest traktowany jako skutek zadziałania pewnej przyczyny. Ową przyczyną musi być coś ontycznego (czyli coś w strukturze bytu), przy czym związek przyczynowo-skutkowy musi mieć charakter rzeczowo-koniecznościowy. Teza o przyczynie ontycznej jest uzasadniana tym, że jeśli zaneguję istnienie tej przyczyny, to zaneguję istnienie danego do wyjaśnienia faktu. Nie chodzi tu o dowodzenie nie wprost, lecz o jedyność i konieczność związków rzeczowych. Słusznie zresztą Autor zaznacza, że takie ujęcie praktycznie eliminuje włączanie hipotez w strukturę teorii bytu (s. 139). Niekiedy pojawia się problem z interpretacją analiz, ponieważ Gondek zamiennie używa „dowodzenie”, „wyjaśnianie”, „uzasadnianie”, „argumentacja”, co jest nieuprawnione, gdyż terminy te mają techniczne znaczenie $\mathrm{w}$ metodologii. Rygor logiczno-metodologiczny jest cechą filozofii klasycznej i należało go utrzymać w kluczowym punkcie omawiania teorii bytu. Prezentacja metod stosowanych w teorii bytu - jako elementu gwarantującego autonomiczność jest jasna wyłącznie dla czytelnika dobrze znającego tradycję szkoły lubelskiej i w miarę biegłego w logice.

Rozdział III rozpoczyna punkt poświęcony wyodrębnieniu przedmiotu metafizyki, gdyż ta operacja determinuje pozostałe procedury w teorii bytu. Słusznie Autor podkreśla, że „sformułowanie właściwego przedmiotu wchodzi już w zakres teorii” - jest to stanowisko współczesnej filozofii szeroko rozumianej nauki i wydaje się, że w tym względzie Krąpiec i Kamiński byli prekursorami. Wyodrębnianie przedmiotu teorii bytu jest bardzo starannie przedstawione. Krok pierwszy to ukazanie specyfiki poznawczego pierwotnego kontaktu człowieka z rzeczywistością w poznaniu zdroworozsądkowym. Poznanie zdroworozsądkowe jest tu istotne, ponieważ jest bezzałożeniowe: jestem „biernym, uwarunkowanym ontyczną strukturą rzeczy, odbiorcą” (s. 143). Odkrywam, że „coś jest”, „rzeczywistość jest czynnikiem sprawczym zachodzenia czynności poznawczej” (s. 147), a to, „co stanowi sedno pierwotnego aktu poznania nie dotyczy porządku treściowego” (s. 148). Dopiero potem pojawia się namysł nad uzyskanymi danymi czy uświadomienie sobie konieczności ich uporządkowania. Stwierdzenie „coś jest” przybiera postać aktu sądzenie, który Krąpiec i Kamiński nazywają sądem egzystencjalnym. „Struktura sądu egzystencjalnego jako rezultatu poznania stanowi sposób 
artykulacji doświadczenia metafizycznego”, a „bezpośredniość i nierefleksyjność w egzystencjalnym poznaniu sądowym staje się gwarancją prawdziwości tego typu poznania” (s. 149). Choć rozważania zawierają liczne powtórzenia, są jasne i pokazują owo metafizyczne doświadczenie, sąd egzystencjalny i jego rolę w budowaniu teorii bytu. W kolejnym punkcie tego rozdziału Autor wyjaśnia metodę separacji i starannie odróżnia ją od metody abstrakcji, która prowadzi do ujednoznacznionego wyodrębnienia treściowej zawartości rzeczy, podczas gdy metoda separacji - bazując na sądzie egzystencjalnym - pozwala wyróżnić w bycie jego czynniki ontyczne i wskazać, iż to byt jako istniejący stanowi właściwy przedmiot teorii bytu. Kolejnym krokiem jest uwyraźnianie przedmiotu metafizyki, które - ze względu na wymiar ogólnoegzystencjalny ma swą specyfikę: „w trakcie uwyraźniania bytu, w którym odsłaniamy i akcentujemy różne od strony treściowej sposoby istnienia, zakres pojęcia „bytu” nie ulega zmianie”. Transcendentalia (efekt uwyraźniania) są „ujmowane jako skróty sądów egzystencjalnych” (s. 165). Autor omawia kolejne transcendentalia (byt, rzecz, jedność, odrębność, prawda, dobro, piękno), a w następnym punkcie - odkrywanie pierwszych zasad (tożsamości, niesprzeczności, odrębności, przyczynowości, celowości i integralności. Są one - jak pokazuje Autor - traktowane jako poznawcze ujęcie transcendentaliów, a w aspekcie epistemologicznym jako zasady myśli. Niestety, te ważne wywody dla czytelnika nie znającego tradycji metafizyki klasycznej i dość wyrafinowanej metodologii i logiki pozostają niejasne. Krok finalny w procedurze systemowego uzasadniania autonomiczności teorii bytu to uniesprzecznienie. Dla klasycznej metafizyki jest to procedura absolutnie kluczowa. Praca Pawła Gondka z pewnością stanie się „klasycznym” źródłem, na które będzie się można powołać. Rozważania są klarowne: starannie rozważone jest metafizyczne ujęcie pluralizmu bytowego ze względu na sposoby istnienia, broniona teza, iż „ostateczne uzasadnienie sposobów bytowania dokonuje się poprzez wskazanie na ontyczną strukturę bytu” (s. 195) oraz objaśnione, czym jest uniesprzecznienie: „Zasadniczym momentem uniesprzeczniającym byt w kontekście doświadczanych stanów bytowych jest wskazanie na czynniki bytowe, które są wyodrębniane ze względu na konkretne sposoby bytowania. Procedura taka opiera się na odkryciu nietożsamości subontycznych elementów bytowych, 
które ostatecznie uzasadniają te stany. Uniesprzecznienie oznacza tu wskazanie na ostateczną (konieczną) rację bytu, której zaprzeczenie byłoby jednocześnie negacją oczywistych faktów ontycznych” (s. 195). Ostatni podpunkt rozdziału III objaśnia owe „czynniki bytowe”, „subontyczne elementy bytowe” i przebieg uniesprzecznienia. Oto w doświadczeniu rzeczywistości odkrywamy stany bytowe: zmienność (dynamizm), przemienność, tożsamość i przygodność. By wyjaśnić, jak te stany są możliwe, wskazane są nietożsame elementy ontyczne: istota-istnienie, akt-możność, materia-forma, substancja-przypadłość. Wprowadzona tu zostaje analogiczność bytu: ,analogia jest sposobem istnienia całej rzeczywistości” (s. 207), ale objaśnienia są niewystarczające, zwłaszcza że zostają wprowadzone także rodzaje analogii, a skrótowe objaśnienia są podane w języku dość hermetycznym. Skoro analogia jest „fundamentalnym czynnikiem systemowym dla budowania autonomicznej metafizyki realistycznej" (s. 209), należałoby rozbudować te rozważania.

Rozdział IV pokazuje konsekwencje wyodrębnienia transcendentalnych własności bytu i złożeń bytowych w postaci szczegółowych dyscyplin w ramach teorii bytu. Natomiast jedność teorii bytu jest gwarantowana odwołaniem się w wyjaśnieniu do racji ontycznych. Metafizyka ogólna jest bazową dyscypliną filozoficzną, wyznaczającą rozumienie przedmiotu, sposobu i celu uprawianej filozofii, natomiast „poszczególne metafizyki szczegółowe wychodzą od danych (o zdecydowanie bogatszej treści), dotyczących jednego typu (kategorii) rzeczywistości” (s. 217). Autor nie rozwija tego twierdzenia. Tymczasem jest ono istotne dla uchwycenia specyfiki klasycznej metafizyki. Chodzi to bowiem o empiryczność teorii bytu i otwartość na rzeczywistość, dzięki czemu możemy budować nowe metafizyki, jeśli pojawi się jakaś nowa kategoria bytu. Podstawę wyodrębniania metafizyk szczegółowych stanowi przedmiot, tj. byt jako byt, którego partykularyzacja jest podstawą wyodrębniania poszczególnych dyscyplin (musi być zachowany realizm i autonomia). Każda partykularyzacja przedmiotu zachodzi na poziomie treściowym i to określa zakresy i typy dyscyplin. Autor starannie omawia, w jakich aspektach metafizyki szczegółowe są samodzielne, a w jakich zależne od metafizyki ogólnej (s. 222n), oraz pokazuje sposób wydobywania nowych danych dla filozofii Absolutu i filozofii człowieka. Osobny punkt poświęcony jest dyscyplinom 
nabudowanym na metafizyce człowieka, tj. tym związanym z postępowaniem (etyka, filozofia prawa) czy wytwarzaniem (filozofia sztuki, filozofia techniki). W tym punkcie szczególnie brakuje głębokiej analizy zależności między naukami, ponieważ powiedzenie, że „tezy zależą” lub dyscyplina „korzysta z innych dyscyplin” niewiele objaśnia. Choć w rozważaniach jest wiele powtórzeń i odniesień do polemik, co grozi zgubieniem głównego wątku rozważań, rozdział ten pokazuje jak żywa i dynamiczna była szkoła lubelska. Rzeczywiście rozwiązywano problemy filozoficzne, trwając przy zasadzie amicus Plato, sed magis amica veritas. Ostatni punkt IV rozdziału poświęcony jest omówieniu dyscyplin metafilozoficznych: logika, teoria poznania i historia filozofii. Autor powraca tu do problemu wykorzystania logiki dla filozofii, dyskusji wokół statusu teorii poznania, wcześniej już pokrótce omówionych, oraz roli historii filozofii. Te ostatnie rozważania są szczególnie cenne, bo uświadamiają czytelnikowi istnienie „filozoficznego doświadczenia” (s. 270). W zakończeniu Autor streszcza główne idee pracy, czyni zastrzeżenia o ominięciu problematyki języka, teorii bytu oraz stawia jako postulat badawczy kontynuowanie dokonań Krąpca i Kamińskiego.

Książka jest zaopatrzona w streszczenie w języku angielskim. Niestety, nie jest to dobre streszczenie. Twierdzenie, że omawiana filozofia jest „,radically” realist philosophy which refers to the fact of existence in the process of defining reality, thus ephasises the general existential scientific aspect" (s. 279) budzi zdumienie, bo doprawdy metafizyka nie definiuje rzeczywistości, a już na pewno nie w ,ogólnym naukowym aspekcie’! Krąpiec i Kamiński zapewne także by się zdumieli, że ich teoria bytu jest „the original project of the philosophical definition of reality" (s. 280). Uważam to za wielką stratę, ponieważ należy propagować wyniki szkoły lubelskiej, zwłaszcza że obecnie w świecie anglosaskim wraca się do problemów i rozwiązań filozofii klasycznej, choć bez świadomości tego faktu. Na podkreślenie zasługuje natomiast bibliografia podzielona na literaturę źródłową, podstawową i pomocniczą (s. 291-311). Dla badaczy i studentów będzie stanowić nieocenione źródło.

Język monografii jest dość trudny, tak jakby monografia pisana była dla czytelnika znającego już tradycję, ponadto jest wiele powtórzeń (dosłownie lub w parafrazie) kluczowych idei. Paweł Gondek uległ też KUL-owskiej 
manierze wielu przypisów (22 we wstępie, 588 w czterech rozdziałach). Są one bardzo interesujące, choć niekiedy lepiej by było, żeby znalazły się w treści pracy, lub zostały ominięte, bo nic nie wnoszą, a są parafrazą tego, co już w treści pracy jest.

W toku recenzji wymieniłam wady i zalety monografii Pawła Gondka. Przy całym krytycyzmie nie mam wątpliwości, że jest to autentyczny wkład w rozwój filozofii i uważam, że jako pierwsza monografia zbierająca idee „projektu” M. Krąpca i S. Kamińskiego z pewnością spełni rolę „zaczynu” dalszych badań. Co więcej, monografia pokazuje, że ów ambitny projekt autonomicznej metafizyki realistycznej nie został do końca zrealizowany i wobec tego wciąż stanowi - by użyć języka Imre Lakatosa - postępowy program badawczy. Ponadto sam projekt, właśnie jako realistyczny i empiryczny, jest otwarty na nowe obszary badawcze. Pozostaje mieć nadzieję, że kolejne pokolenia lubelskich filozofów będą się w ten program angażować.

\footnotetext{
AGNIESZKA LEKKA-KOWALIK

alekka@kul.lublin.pl

Katolicki Uniwersytet Lubelski Jana Pawła II, Instytut Filozofii, Katedra Metodologii Nauk

al. Racławickie 14, 20-950 Lublin
}

DOI 10.21697/spch.2016.52.1.32 